\title{
Enterprise Fragmentation in the Czech Transformation: Emerging Patterns of Dependence and Independence
}

\author{
Ed Clark $^{* *}$
}

This paper examines the process whereby the former state-owned enterprises in the Czech Republic have been fragmented and repackaged into privatised and private firms. By studying the process in two local communities, this research enriches the statistical picture compiled by economists working within a neoclassical paradigm. The findings highlight the diversity of fragmentation patterns and the role played by community, enterprise and management factors. They throw doubts upon the claim that fragmentation has in any simple way created new, independent entrepreneurial firms. The processes of fragmentation do however point to the emergence of distinctive forms of local economic organisation.

In dieser Arbeit wird untersucht, auf welche Art und Weise alte Staatsunternehmen in der tschechischen Republik geteilt und in privatisierte und private Unternehmen umgewandelt wurden. Durch die Studie in zwei Gemeinden wird das statistische Gesamtbild bereichert, das von Ökonomen, die nach dem neo-klassischen Paradigma arbeiten, aufgebaut wurde. Die Untersuchungsergebnisse heben die Unterschiedlichkeit der Fragmentierungsmuster ebenso hervor, wie die Rollen, die von der Kommune, vom Unternehmen und von verschiedenen Managementfaktoren gespielt werden. Nach dieser Studie darf an der Behauptung gezweifelt werden, dass Fragmentierung auf irgedeine einfache Art und Weise neue, unabhängige Unternehmen geschaffen hat. Die Fragmentierungsprozesse bringen jedoch verschiedene Formen lokaler ökonomischer Organisation ans Licht.

\footnotetext{
E* Ed Clark is Senior Lecturer in Organisation Studies at the School of Management, Royal Holloway, University of London. His main research interests focus on the processes of enterprise transformation and management change in the transition economies of central and eastern Europe.
} 


\section{Introduction}

Building a market-oriented system out of the economic structures of state socialism has been one of the main challenges confronting the former communist countries of Central and Eastern Europe. The size of this challenge was at its greatest in the former Czechoslovakia, where the forces of centralisation, following the post-1968 re-imposition of economic "normalisation", had reinforced the economic tendencies of Stalinist planning to organise production in increasingly large industrial structures (see Kornai 1980; Rychetník 1981). By 1989, some 700 industrial enterprises ${ }^{1}$, many with multiple plants in a variety of locations (Vyrobní Hospodařké Jednotky or VHJs), employed on average more than 3,000 staff (e.g. Jeffries 1993: 248; Mejstř́k 1993: 125; Myant 1993: 158; Lízal et al. 1995: 219).

As Czechoslovak command-economic structures were dismantled, to be replaced by more market-oriented institutions, the initial number of enterprises expanded rapidly through processes of splits and break-ups (Charap/Zemplinerová 1993). Lízal et al. (1995: 226) claim that by the end of 1991 the 700 state-owned enterprise structures had spawned 1,855 independent post-communist companies. In June 1991, the Czechoslovak Ministry of Privatisation published lists for the Czech Republic, enumerating some 3,500 enterprises - nearly 5,500 for the whole of Czechoslovakia (see Mládek 1993: 132; also Kotrba 1995). Moreover, Dlouhý/Mládek (1994: 158) report that in December 1993 over 7,500 "units" of property (not all "industrial") had been transferred to the National Property Fund (NPF) as part of the process of large privatisation. A cursory examination of such statistical details reveals very little consensus over quantitative patterns in this multiplication of economic units and even less examination of the diversity within them.

The rate of enterprise fragmentation - as I shall call this process of splitting the assets of the former state-owned enterprises (SOEs) into smaller organisational bundles - can be understood as an indicator of the success of economic transformation at the level of the local productive unit. Economists argued that breaking up the old industrial monopolies enabled the achievement of a variety of desirable organisational and management changes through the effective decentralisation of economic action. Such benefits included greater levels of price and cost consciousness, more awareness of markets and customers, the reduction of wasteful administration costs and the improvement of management incentives, innovativeness, and entrepreneurialism (see, for example, Myant et al. 1996: 182-183).

\footnotetext{
1 The cited numbers of enterprises and their size vary from source to source, largely because of ambiguities in the administrative structures of central planning in 1989. This figure specifically refers to industrial enterprises employing over 25 people.
} 
Economists have typically examined enterprise fragmentation by turning to orthodox neo-classical economic reasoning: it is a process that denotes significant moves towards a more liberal business environment, whose Westernstyle constraints force economic actors to undertake rational restructuring. Yet the construction of theoretical explanations of microeconomic processes by resorting to a predominantly economic syntax and drawing on a macro database - particularly if officially compiled for government purposes - is fraught with problems of validity. Such pictures tend to neglect any complicating, ambiguous or obfuscating processes that are the product of social, personal and political factors at the micro level and lead in practice to diversity of pattern. The conceptual tools of transition economics predispose research towards examination of a narrow range of economic factors and its vision is stubbornly resistant to counter-evidence (e.g. Myant 1999: 146-148).

In this paper, I focus on the micro realities of enterprise restructuring, as experienced within six formerly SOEs, typical in many ways of Czech organisation. These enterprises have dominated the social and economic life of managers, employees and their families in two communities in the Czech Republic. My aim is to explore the patterns of enterprise restructuring in their local contexts as revealed in the processes whereby pre-1989 enterprise assets have been split off to create new socio-economic structures. By doing so, I examine the economic and organisational implications of enterprise fragmentation, whether the creation of multiple economic fragments has actually been associated with the multiplication of new, independent and competitive firms. By taking such an angle, detailed case research is an important complement, and at times antidote, to the more generalising research of transition economists. Close observation of actual processes of enterprise fragmentation within their socio-economic contexts can enable a more discriminating understanding of how macroeconomic processes and pressures are fashioned and adapted by motivated social actors in their local social circumstances.

The paper is divided into four sections and a conclusion. The first section sets the scene by describing the essential structural features of state-owned enterprises as complex, multifunctional collections of assets, and develops the conceptual framework for examining fragmentation as socio-economic process. This leads to a section outlining the research and the case enterprises in their local contexts. The third section presents evidence of the fragmentation patterns observed in the two communities and arguments to explain the findings in terms of the earlier framework. The fourth section considers the implications of the findings for the development of local economic structures, before the paper draws some general conclusions. 


\section{Enterprise restructuring: the historical and social context}

While enterprise restructuring has taken place within the particular historical context of Czechoslovak State socialism, transition economists have focused specifically upon the contemporary relationships between ownership change, enterprise restructuring and the development of market-economic business conduct. The transferral of state assets into private hands has been taken as the prerequisite for the effective restructuring of the SOE. Within a neo-liberal framework, prior privatisation was thought to ensure that enterprise restructuring was conducted according to the wishes of concrete owners with a utility maximising incentive to organise their acquisitions efficiently (see Frydman/Rapaczynski 1994: 46ff; also Myant 1993; Richet 1993). The view that the prior repackaging of large SOEs into more attractive bundles was necessary to entice private (especially foreign) investors (e.g. Carlin/Landesmann 1997; Hirschhausen 1995; McDermott 1997; Myant 1993) has been a minority influence, but the neo-liberal view has been embodied in Czech rapid mass privatisation policy. Despite the prominence of neo-classical policy advice, an explanation of the realities of enterprise restructuring and of the main obstacles it confronted requires a greater understanding of the nature of the organisational form inherited from the pre-1989 command-economic hierarchy.

Within state socialism, SOEs - be they VHJs or the large subsidiary production units - had objectives beyond the familiar economic functions of production of core goods and services. As economic systems, they developed high degrees of autarchy, creating many internal ancillary activities like maintenance, design, repair, technical support, personnel and so on (cf. Richet 1993: 231). However, unlike market-economic industrial companies, SOEs also served political and social functions. In their political structures, they provided on-site mechanisms through which the Communist Party could maintain surveillance over production processes, the labour force and the management cadres. Simultaneously, SOEs were the conduits for the delivery of many of the State's social and welfare benefits - including health, housing, child care, holiday, recreation and sports (see, for example, Commander/Schankerman 1997; Soulsby/Clark 1995). These triple functions were defining features of the industrial organisational form.

As a consequence of their status as "multi-functional units" (Hirschhausen 1995: 57), the larger SOEs tended to be integrated into the social and political structures of their local communities - the more so in small communities dominated by large enterprises (see Clark/Soulsby 1998). Despite the powerful centralised pull of command-economic formal institutions, Czechoslovak managers, like those elsewhere in the region, had to engage in informal practices, bordering on the deviant (cf. Clark/Soulsby 1999a: 83ff.). For example, to solve supply and production problems inherent in the command 
economy, they cultivated institutionalised practices such as vertical and horizontal networking, thereby creating “... tight social and economic links between suppliers and customers, firms and banks, as well as firms and their localities" (McDermott 1997: 74).

In this socio-economic context, the success of SOEs was measured not only in terms of their economic prowess, reputation, exporting ability and product quality - though these were certainly matters of local pride. Enterprises were also judged by their ability to attract and allocate decent housing, to draw state money towards the region for cultural, sports and recreational facilities, to offer good levels of in-house education, child care and medical services, and to provide for their employees and their families highly subsidised holidays and sanatorium breaks in their own camps, hotels and parks in peaceful beauty spots. In accumulating these facilities, enterprise managers fulfilled the political objectives and social norms of the dominant communist ideology.

Following the collapse of communism and its institutional rules and yardsticks and the acceptance of industrial capitalist aspirations, social and productive assets in the prevailing structural combinations became subject to Western rules of technical efficiency and formal rationality. Imported standards of marketeconomic accountability and the discipline of capitalist accounting transformed overnight the value and meaning of the SOE as an asset structure. The new economic philosophy emphasised de-monopolisation, focus on core activities, decentralisation of control and the flexibility and economic advantages of smaller, more mobile firms. Post-communist managers keen to survive or prosper in the transitional environment ignored at their peril the new economic precepts: to maximise returns, to minimise factor costs, to reduce administration costs and to ensure streams of income from all "assets".

A central restructuring problem was how to break down the existing asset structures and reassemble them in new combinations that would satisfy the guardians of the new economic discipline (compare Stark 1997). The multifunctional SOE inevitably became subject to two processes of fragmentation. Economic fragmentation has resulted from the application of Western market logic to the facilities and services that had been accumulated to promote autarky in production, many of which had become inefficient, unprofitable and peripheral to the enterprises' main economic activities. The repackaging of these economic liabilities into smaller independent units was an opportunity to inject these activities with their own market-economic rationality. Social fragmentation refers to the spinning off of social facilities, some of which (e.g. holiday camps) could be redefined as economically viable assets using the same principle. Most, however, had little or even negative market value and remained unreconstructed enterprise liabilities, alongside other social property such as houses, schools and kindergarten. 
In terms of theoretical simplicity, it is attractive to explain enterprise restructuring by presuming that economic actors take decisions by applying a fixed rationality of utility maximisation (cf. Etzioni 1988) within the constraints of the contemporary economic and institutional environment. However, as we shall show below, this assumption does not entirely accord with observations of management conduct. Studying the enterprise within its community permits the construction of a more finely grained account of fragmentation patterns. Figure 1 offers a highly simplified diagrammatic representation of the theoretical reasoning behind the socio-economic perspective adopted in this paper.

The diagram highlights three sets of important factors: those relating to the role of human agency, those referring to the influence of "external" macro constraints and those referring to "external" local (community and enterprise) influences on fragmentation. At the heart of the argument is the proposition that actual decision-making practices reflect the varied objectives, values and motives of these key stakeholders in the enterprise. As a result, the fragmentation and repackaging of assets are likely to take different courses in different enterprises at different times. The creation of independent economic units may ensue from classical rational-economic motives, as embodied in decisions by concrete private owners to streamline assets and activities in order to be more cost-effective, efficient or profitable. However, as the author demonstrates later, this does not exhaust the rationales for restructuring assets and liabilities. The conduct of socially located economic actors is the critical explanatory factor, because socio-economic action always takes place within an environment, which it enacts, resists, or adapts according to the degree to which external factors are felt as constraining or facilitating.

Figure 1 therefore also points to the importance of the environment of enterprise restructuring, conceptualised as three analytically distinctive sources of influence. First, the transformation context has macro economic and institutional features, which vary according to the particular phase of transition (see below). The micro-landscape of the business environment has two dimensions. On the one hand, the socio-economic community is important in the consciousness of enterprise management because of the enterprise's historical centrality in local matters. On the other hand, the enterprise itself is the socio-economic location of strategic decisions and its experiences and traditions inevitably influence managers as participants in the organisational process. Each of the three contextual factors has both contemporary and historical dimensions. In particular, the institutional, management and cultural legacies of the former command-economic structures, of the SOE and of enterprise-community linkages constitute social resources upon which postcommunist decision-makers can draw in order to manage the process of enterprise restructuring within the ambiguous context of the economic transition. Historical legacies have a specially enduring influence on current thinking, loyalties, commitments and practices when the decision-makers are 
former nomenklatura (cf. Clark/Soulsby 1996). The discussion of the empirical cases of enterprise fragmentation, below, explores the complex, interwoven nature of contextual and human agency factors outlined in this framework.

Figure 1: Factors in the Process of Enterprise Fragmentation

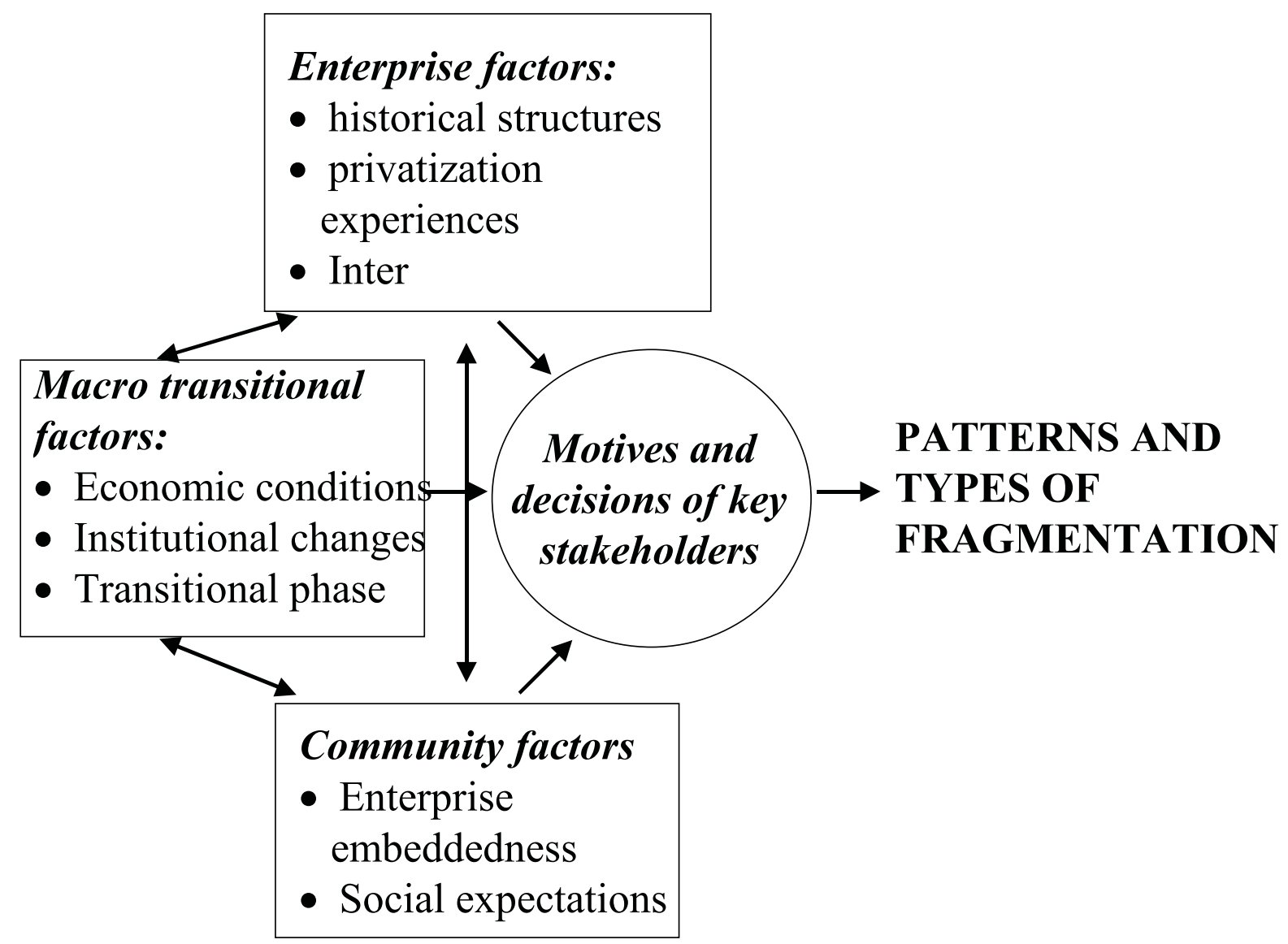

\section{Two Czech communities and six enterprises}

The author has been conducting research in the two Czech industrial towns of Volna and Jesenice ${ }^{2}$ since 1992, during which time a wide variety of materials have been collected. First, official documents published by both the town authorities and the former SOEs have been assiduously amassed. Second, questionnaires were sent during 1998 to senior management contacts in each enterprise in order to assemble a "factual" picture of fragmentation and repackaging of assets - the key source of many of the quantitative data presented below. Third, and most important, are the qualitative materials accumulated through intensive interviews with major players in the two towns, in each case starting from detailed work in each community's largest pre-1989 SOE (see Clark/Soulsby 1999a). Additional respondents include the enterprise

2 All names of towns and enterprises have been anonymised in this paper. Confidentiality has been an agreed condition of most of the research upon which this paper is based. 
Table 1: Privatisation and Restructuring of the Six Enterprises

\begin{tabular}{|c|c|c|c|c|c|c|}
\hline & \multicolumn{3}{|c|}{ JESENICE } & \multicolumn{3}{|c|}{ VOLNA } \\
\hline & JS a.s. * & $\begin{array}{l}\text { Vojenz a.s. } \\
*\end{array}$ & $\begin{array}{l}\text { Zachem } \\
\text { a.s. * }\end{array}$ & $\begin{array}{l}\text { Jekuf s.r.o. } \\
*\end{array}$ & Vols a.s. * & $\begin{array}{l}\text { ZAKOV } \\
\text { a.s.* }\end{array}$ \\
\hline $\begin{array}{l}\text { Employ- } \\
\text { ment } \\
1989\end{array}$ & $7,000 \dagger$ & $4,000 \dagger$ & 1,600 & $500 \dagger$ & 5,600 & $1,700 \dagger$ \\
\hline $\begin{array}{l}\text { Employ- } \\
\text { ment } \\
1997\end{array}$ & $3,000 \div$ & $1,800 \div$ & 800 & 450 & 3,600 & 712 \\
\hline $\begin{array}{l}\text { Privati- } \\
\text { sation in- } \\
\text { volve- } \\
\text { ment }\end{array}$ & $\begin{array}{l}1 \text { st and } 2 \text { nd } \\
\text { waves }\end{array}$ & $\begin{array}{l}\text { 1st wave } \\
\text { only }\end{array}$ & $\begin{array}{l}\text { 2nd wave } \\
\text { and public } \\
\text { auction }\end{array}$ & $\begin{array}{l}\text { Restitution } \\
\& \text { private } \\
\text { sale }\end{array}$ & $\begin{array}{l}1 \text { st and } 2 \mathrm{nd} \\
\text { waves }\end{array}$ & $\begin{array}{l}\text { Restitution } \\
\& \text { public } \\
\text { auction }\end{array}$ \\
\hline $\begin{array}{l}\text { Privati- } \\
\text { sation } \\
\text { problems }\end{array}$ & $\begin{array}{l}35 \% \text { shares } \\
\text { withheld } \\
\text { for foreign } \\
\text { capital in } \\
1 \text { st wave }\end{array}$ & $\begin{array}{l}\text { Ownership } \\
\text { widely } \\
\text { dispersed }\end{array}$ & $\begin{array}{l}\text { Unrealised } \\
\text { foreign } \\
\text { interest } \\
(1992) \text {; } \\
\text { 2nd wave } \\
\text { shares } \\
\text { withheld } \\
\text { for foreign } \\
\text { capital }\end{array}$ & $\begin{array}{l}\text { Restitution } \\
\text { squabbles }\end{array}$ & $\begin{array}{l}20 \% \text { shares } \\
\text { unsold and } \\
\text { dispersed } \\
\text { ownership } \\
\text { after 1st } \\
\text { wave }\end{array}$ & $\begin{array}{l}\text { Unrealised } \\
\text { foreign } \\
\text { interest } \\
(1992) \text {; } \\
\text { restitution } \\
\text { problems; } \\
\text { auction } \\
\text { results } \\
\text { contested }\end{array}$ \\
\hline $\begin{array}{l}\text { Privati- } \\
\text { sation } \\
97 \% * *\end{array}$ & 1994 & 1993 & 1996 & $\begin{array}{l}\text { December } \\
1997\end{array}$ & 1994 & $\begin{array}{l}\text { October } \\
1998\end{array}$ \\
\hline $\begin{array}{l}\text { Organi- } \\
\text { sation } \\
\text { Structure } \\
1997\end{array}$ & $\begin{array}{l}\text { Holding } \\
\text { company }\end{array}$ & $\begin{array}{l}\text { Holding } \\
\text { company }\end{array}$ & $\begin{array}{l}\text { Core } \\
\text { production } \\
\text { in divi- } \\
\text { sions, ser- } \\
\text { vices out- } \\
\text { sourced }\end{array}$ & Functional & $\begin{array}{l}\text { Core } \\
\text { production } \\
\text { in divi- } \\
\text { sions; ser- } \\
\text { vices in } \\
\text { daughters }\end{array}$ & $\begin{array}{l}\text { Divisional } \\
\text { form }\end{array}$ \\
\hline
\end{tabular}

* Akciová společnost (a.s.) is a publicly quoted joint-stock company. Společnost s ručením omezeným (s.r.o.) is the private limited liability form. They are partly defined in terms of minimum asset value.

** Each enterprise had to contribute 3\% of its shares to the Restitution Fund to cover restitution claims that were not realisable in terms of property.

$\dagger \quad$ Information refers only to enterprise activities based in the respective communities.

$\$ \quad$ These figures include all those employed by the daughter companies.

directors of the other main enterprises, the founders of new private firms, the post-communist mayors, their deputies and local government employees. The 
resulting sample comprises 55 respondents from Jesenice and 30 from Volna. Neither the respondents, nor the enterprises nor their communities can, in any accepted statistical sense, be called "representative", though their state socialist and post-communist experiences would be recognisable by most Czechs as more or less typical of their kind.

The economic and social welfare of the 23,000 population of Volna (1989) had been assured by the presence of two SOEs, Vols and Zakov. Vols was by far the largest and most influential, having been established in 1948 as a heavy engineering enterprise whose expansion was strongly supported from the centre as a strategic economic operation. The private predecessor of Zakov had been nationalised in 1948 and had grown through the expansion of its traditional range of small metal products. Jesenice is the home of the other four enterprises, though there were other medium sized SOEs in the district. Zachem was a member plant of the pharmaceutical industrial branch, while Jekuf was constructed by the nationalisation in 1948 of a private travel equipment firm. However, it was the activities of the other two SOEs that led to the reputation and expansion of the town. Vojenz was a successful manufacturer of military equipment for Soviet bloc allies, while Jesenické Strojírny (JS) grew rapidly because of its role as a supplier of heavy construction machinery.

Jesenice and Volna are in many ways typical products of economic growth under state socialist policies of rural industrial development, and their welfare became dependent on the success of the dominant enterprises (see Clark/Soulsby 1998). The social, economic and political importance of the largest enterprises - Vols in Volna, JS and Vojenz in Jesenice - were not just a question of their size. Their location in strategic industrial branches was crucial, because such enterprises attracted significant funds for both economic and social-cultural construction. In the ongoing political negotiations between the district and the central Party organs for local development, these enterprises were themselves critical resources. They built their own blocks of apartments and had usage rights over state-owned apartments. Directly or indirectly they each contributed to the construction of sports facilities, cultural centres, hotels, recreation and holiday camps, kindergarten, schools and training centres, polyclinics, cinemas and so on, whose administration they undertook as a duty. After 1989, the six enterprises have had different restructuring and privatisation experiences, as summarised in Table 1, below.

\section{Patterns of economic fragmentation}

The remainder of this article presents the complex picture of the new asset combinations consciously fragmented and privatised from the initial property of the six state enterprises. The findings actually understate the degree of overall enterprise fragmentation. First, the table makes no reference to former enterprise social facilities that have ended up in the hands of non-economic 
agencies. Although the SOEs had had de facto control of social assets, in 1990 many were deemed to be the legal property of the state. Even when social property did belong to the SOE, it often had little market value and high maintenance costs. Many social facilities have therefore been fragmented and redistributed to other agencies such as the municipality, the state, voluntary clubs, trade unions and private individuals. Second, the data take no account of any further splits that may have taken place within the separated structural fragments. Detailed knowledge of one of JS's fragments - Montáze Jesenice confirms that significant "secondary" fragmentation was normal. Third, because of incomplete information, various small leasing and renting activities of the SOEs can only be acknowledged rather than counted. Despite these shortcomings, we can discern a number of patterns and processes of enterprise fragmentation by using tabulated data supported by qualitative materials.

\section{The broad patterns}

Five of the six SOEs had themselves been formed as fragments of larger VHJ structures. Given the above caveats, the six former SOEs have broken into 60 economic-structural fragments, each with its own legal status (see Table 2). The fragments vary in size, and the vast majority of fragments (52 of the 60) were formed within the respective towns and most of these actually continued to operate on the same premises as before 1989. The overall ten-fold increase in organisational units conceals real and significant patterns. For example, the logical expectation of a relationship between original SOE size and number of fragments created is not straightforward. Despite the largest SOE (JS) spawning most new companies and the smallest (Jekuf) the fewest, Vols, the second largest, has split off only half as many as Zachem, though it was three and a half times larger. Nor does the application of business-economic logic by itself explain the findings. For example, the highly integrated nature of JS's main turnkey business was not, apparently, a barrier to its high propensity to fragment. These observations underscore the importance of considering other, perhaps less obvious, factors.

In order to explore these variations within the theoretical framework presented in Figure 1, the argument below examines the role played by two broad sets of factors. First, I shall show that different patterns of fragmentation were associated with the changing nature of the dynamic transitional context of each enterprise, emphasising the systematic influence of transitional phases. Second, I shall consider the importance of micro socio-economic processes in creating a diversity of restructuring pattern and process within the six enterprises. At an 'objective' level, this highlights variations due to enterprise-specific factors (such as historical legacies and organisational culture) and ways in which the enterprises are embedded in their local communities. But at the heart of this theoretical interpretation are the roles enacted by enterprise managers with ultimate restructuring responsibility. It is their decision making conduct, guided 
by values and motives, that have mediated between the transitional business context, the local socio-economic environment and the eventual patterns of fragmentation observed.

Table 2: Primary economic fragmentation (1990-1998)

\begin{tabular}{|c|c|c|c|c|c|c|c|}
\hline & \multicolumn{4}{|c|}{ JESENICE } & \multicolumn{2}{|c|}{ VOLNA } & \multirow[b]{2}{*}{ Total } \\
\hline & JS & Vojenz & Zachem & Jekuf & Vols & Zakov & \\
\hline $\begin{array}{l}\text { New companies } \\
\text { formed in the } \\
\text { community }\end{array}$ & 18 & 7 & 17 & 0 & 8 & 2 & 52 \\
\hline $\begin{array}{l}\text { New companies } \\
\text { formed elsewhere }\end{array}$ & 0 & 2 & 0 & 3 & 0 & 3 & 8 \\
\hline $\begin{array}{l}\text { Total } \\
\text { economically } \\
\text { active fragments }\end{array}$ & 18 & 9 & 7 & 3 & 8 & 5 & 60 \\
\hline
\end{tabular}

\section{The phases of transition}

As new institutional principles and structures began to transform the socioeconomic system of Czech post-communism, industrial enterprises and their managements had to select ways of responding to these changing circumstances. The transition environment has not been an unambiguous, unitary factor in the story of enterprise restructuring, because, by definition, its characteristics have unfolded in relation to economic and institutional change. As the transformation has proceeded, enterprises and their managers had to cope with new and changing conditions. In retrospect, the transition business environment can be analysed in terms of a series of interwoven and overlapping phases, each defined by key economic and institutional features. Although any attempt to splice a continuous process into distinct "stages" has to be handled with sensitivity, the evidence of fragmentation gives some prima facie support for conceptualising four discernible phases up to 1997.

During the first year of the transition, the government had to work largely within the existing institutional framework, while preparing for fundamental changes in legal, social and economic structures. This was a period of continuing state regulation, for the government was the only major source of important economic initiatives. The first round of enterprise fragmentation falls within this period, and, in keeping with the phase, took the form of imposed state decisions to create new enterprises from the larger SOEs. Thus in 1990, four of the SOEs were told to spin off a total of nine new state enterprises, mostly large, core production or service plants (see Table 3 ). In each case, these 
new enterprises continued to be major suppliers of materials, components or services to their former mother companies.

Table 3: Fragmentation and transition phases

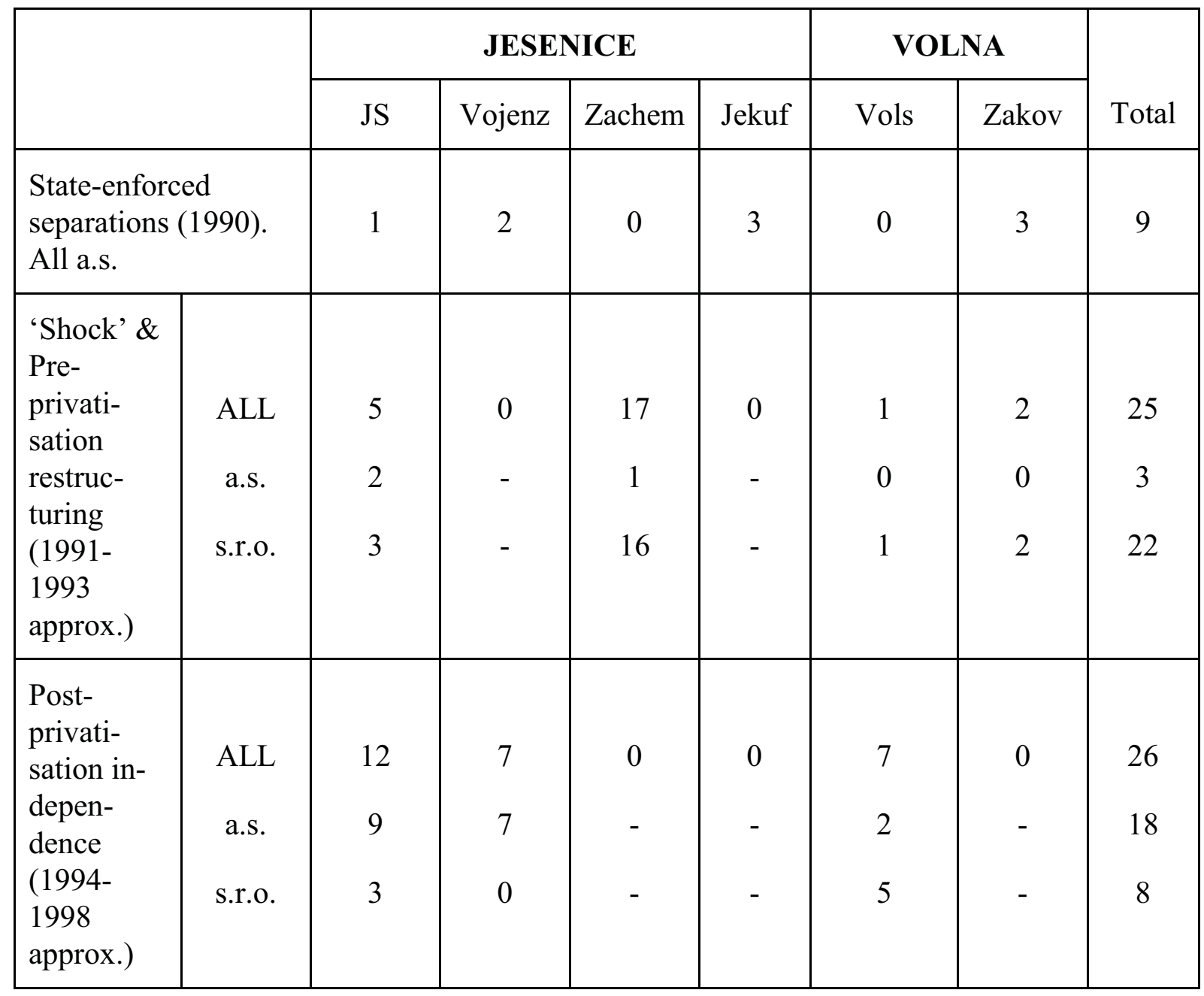

At the same time, property rights over social facilities were clarified and this resulted in the forced (but rarely contested) separation of many facilities over which enterprises had exercised de facto rights of control. Thus state housing was legally placed on the books of municipalities. Sports stadia (football, ice hockey, athletics etc.) and recreation facilities (such as swimming pools) had often been built through schemes (like the ideologically inspired Akce Z) jointly managed and funded by local authorities and large enterprises, and their operations had been effectively administered through enterprise structures. What one JS manager called a "mess of ownership" was sorted out in 1990 by the assertion of state rights over these assets and allocating them to voluntary sports associations and social clubs.

The second transitional phase of shock (see Myant 1999; 1993) resulted from the economic liberalisation programmes through which the government released price and trade constraints. Jekuf, with its predominantly domestic orientation, 
was the only enterprise to escape the painful consequences of the simultaneous collapse of the Council for Mutual Economic Assistance (CMEA). The collapse of military markets (accelerated by new government policy) affected the heavy engineering products of Vols and JS, but forced Vojenz to close down threequarters of its production capacity. Zachem lost its core production as a result of being exposed to global competition for its hitherto protected pharmaceutical products.

Overlapping with the period of shock was the start of the privatisation process, involving restitution, and small and large privatisation. From 1991 onwards, in this privatisation phase, most large SOEs had to devise privatisation strategies using the well-documented methods (e.g. Kotrba 1995; Dlouhý/Mládek 1994; Mládek 1993). Privatisation took place over a variable period, its length depending on enterprise-specific circumstances. While Vojenz was privatised in a two-year period (1991-1993) - the only enterprise to sell all its shares in the first wave - Zakov had to wait an agonising seven years. The start of privatisation coincided with the shock reverberations and led to patterns of fragmentation aimed at consolidating the basic strength and minimising the inherited weaknesses of the SOE.

This voluntary creation of new fragments led to a very different pattern from the large plants and factories detached through state regulation. In order to survive, enterprise managers turned to those economic and social assets that could be transformed into economically viable and productive assets. The closure of whole production lines at Vojenz and Zachem released a lot of factory and office space as well as machinery. For these enterprises, it was critical to find ways of making their unused assets pay, and they did so by leasing, renting or selling them. Zakov, which had enjoyed a strong reputation in the manufacture of certain sports equipment, lost its extensive Russian markets virtually overnight. Senior managers persuaded a group of enthusiastic employees to lease property as a private firm and continue production of these products. Moreover, most enterprises were more or less forced by these circumstances to consider (often disadvantageous and demeaning) commercial arrangements with foreign partners in order to utilise their technology and labour force.

In Phases 2 and 3, then, enterprises typically spawned small private firms (see Table 3), whose previous functions had been the provision of peripheral services (see Myant 1999: 152-153). For example, seven of the ten new economic units separated from JS during its privatisation (1991-1994) were regional sales offices, training facilities, and hotels. A further two were 'sink structures' or 'residual enterprises' (Carlin \& Landesmann 1997: 87) - one aggregated poorly performing social assets, the other organised the completion of an inherited CMEA investment project from which trade credits had in 1990 been withdrawn. The final fragment was a production plant that had been at the heart of JS's most profitable pre-1989 business in Russia - a business in deep 
economic trouble by 1993. Similarly, Vols split off canteen services and supplier of technical gases, while Zakov sold its energy generating plant as a management buy-out.

The fourth phase was characterised by the enterprise completing the privatisation process. Like Phase 3, post-privatisation has no specific starting time. For example, Jekuf, Zakov and Zachem arrived in this phase too recently to make any reliable observations. In the first two cases, privatisation was delayed by restitution complications, while the latter's problems came from the National Property Fund's insistence on attracting foreign capital. The approach to fragmentation by the three remaining former SOEs - coincidentally the three biggest - has been very similar.

Since privatisation, each of these three enterprises has moved towards the adoption of a holding company form and the creation of new daughter (subsidiary) companies. Only Vols has refrained from making this ultimate of decentralising moves (see Clark/Soulsby 1999b). Between them they spawned twenty six wholly or majority owned subsidiaries with legally independent status (Table 3), eighteen of which have taken the joint stock company form, 15 of which were core production facilities. Again, Vols is the exception - having retained its divisionalised structure, it has separated only one core production subsidiary. During this period, the fragments have been relatively large and have tended to include the key production and service plants, leaving the holding company structure as a strategic management centre.

This analysis suggests that patterns and types of fragmentation are related to the dynamics of the transition process, but, given the variations identified, it also demonstrates that the external economic and institutional conditions are by themselves an insufficient explanation. We now turn to consider how patterns of enterprise fragmentation were influenced by factors originating in the local circumstances of the enterprises and by the ways in which managers have attempted to control the process from within.

\section{Local influences: enterprise, community and management factors}

The patterns of fragmentation varied quite sharply between the six individual enterprises and between the two communities, and these variations can be associated with a complex set of local circumstances. This section considers three analytically separate but empirically interrelated processes: the particular legacies and problems of each enterprise; the impact of local community factors; and the role of enterprise managers as key decision-makers mediating the pressures arising from the national and local transition environments and the internal organisation.

In each SOE, special circumstances framed the decisions to fragment. For example, the low propensity for break-up in Jekuf and Zakov was in part related to their relatively small starting size, but more than anything else restructuring 
was affected by their own experiences of privatisation. Both enterprises had a distinctive pre-war history of private family ownership, which marked them out from the other enterprises that had been assembled through nationalisation of corporate units and/or built up anew. The post-communist development of both Jekuf and Zakov was systematically drawn out by contested restitution claims, during which process it was difficult for managers to make decisions to change enterprise asset structures. Even thus constrained, the General Director of Zakov was able to exert some control over the restitution proceedings in order to further his ambition to privatise Zakov for his own benefit. Since the restituent was unable to raise money to buy Zakov as an ongoing concern, the General Director directed the claim towards those assets that had been leased to former employees to continue production of sports equipment (see above). In doing so, he was able to deflect attention away from the enterprise's main production assets, and, after a long tussle, he took over ownership of Zakov with a successful auction bid in 1998 .

At the other end of the scale, Zachem had by far the highest rate of fragmentation (see Table 4), again a consequence of its particular exigencies mediated by management decision-making. As a result of the economic and institutional shocks, its core production programmes had been decimated by the loss of key markets. Further, the privatisation of Zachem was delayed by the government's expressed desire to find a foreign owner - the enterprise was withdrawn from the first wave and the NPF held back more than $50 \%$ of its assets from the second wave. In these circumstances, Zachem's long-suffering "interim" management consciously adopted a policy of allowing small independent firms to lease or buy its plant and premises in order to outsource its own production needs, to redeploy its own labour force and thereby to reduce costs. From the senior managers' perspective, this recombining of assets in small on-site packages was crucial to the medium-term survival of the enterprise.

The restructuring and fragmentation of Vojenz is a very specific story, because its post-communist travails were founded on its pre-1989 industrial success. A senior manager commented that they had "lost everything". From being a fully independent and autarchic enterprise in 1989, its military production - formerly $75-80 \%$ of its capacity - was stopped and the enterprise had to cut its work force, close plants and develop new products. The lack of voluntary separations during the early period (Table 3 ) is a direct consequence of this corporate catastrophe - assets and activities that might in other circumstances have become fragments were in fact simply written off and shut down. With so much vacant capacity, Vojenz's management adopted a policy, like Zachem, of mass renting of factory and office space, and with government financial help, acquired the patent and plant for a modern automotive component. The enterprise re-organised its remaining civilian production into divisions and entered the first wave of privatisation. Its apparent success in the first wave was 
tempered by the fact that $90 \%$ of the shares had been bought by individuals, leaving it in a control vacuum with no new sources of capital. Only through the increasing financial and management participation of a foreign partner did Vojenz finally develop a strategic direction and, in 1996 it adopted a holding company form, which spun out seven new daughters.

These enterprise-specific stories conceal a larger pattern that can be seen in Table 4. Collectively, the four enterprises in Jesenice have a rate of fragmentation more than twice as great as the two enterprises in Volna, suggesting that enterprise restructuring may in some way be affected by the community itself. It is possible to explore these effects more closely by concentrating on the fragmentation of Vols and JS, the leading enterprises in the two communities. The case of Vols and Volna is particularly informative of the ways in which a close enterprise-community relationship - typical of many "industrial villages" forged in the heat of communist industrialisation - has continued to influence enterprise-level decision making (see also Clark/Soulsby, 1998). When the centre assigned new social assets to Volna - a typical "communist town" - they were placed under Vols' stewardship and at Vols' disposal. As the enterprise and town had grown up together, it is not surprising to find respondents agreeing that "Volna is Vols".

Table 4: Rate of fragmentation by enterprise and community

\begin{tabular}{|c|c|c|c|c|c|c|c|}
\hline & \multicolumn{4}{|c|}{ JESENICE } & \multicolumn{2}{|c|}{ VOLNA } & \multirow[b]{2}{*}{ Total } \\
\hline & JS & Vojenz & Zachem & Jekuf & Vols & Zakov & \\
\hline $\begin{array}{l}\text { Number of SOE } \\
\text { employees per local } \\
\text { fragment (by } \\
\text { enterprise) }\end{array}$ & 388 & 444 & 94 & - & 700 & 850 & 392 \\
\hline $\begin{array}{l}\text { Number of SOE } \\
\text { employees per local } \\
\text { fragment (by } \\
\text { community) }\end{array}$ & \multicolumn{4}{|c|}{312} & \multicolumn{2}{|c|}{730} & 392 \\
\hline
\end{tabular}

The consequences of such embeddedness for restructuring decisions cannot be underestimated. Throughout the interviews from 1992 till 1998, Vols' postcommunist senior managers have consistently espoused and enacted values and practices that are reminiscent of their state socialist obligations as former nomenklatura managers. At times dubbed with the epithet 'pink', these managers found it impossible to contemplate decisions that cut across their genuinely felt duty to Volna and its residents. The data on the fragmentation of Vols are consistent with this strong reluctance to inflict social and economic damage to Volna. Despite its formal market-economic rhetoric, the enterprise 
has maintained much of its social and economic property intact. It still owns and finances its recreation and holiday areas, its hotels and its culture house, but has complied with state rulings about its housing and sports facilities. Vols' economic fragments have been on-site, very small service suppliers, and only one of these was separated before December 1993. Exceptionally in 1994, Vols split off one of its main production plants as a daughter company, but even this was symptomatic of Vols' gradualist philosophy of restructuring. This plant had been under serious threat of closure following the shocks of 1990-1991 and Vols' senior management had nurtured it through these hard times and until its recovery was complete.

Vols' low rate of fragmentation results from maintaining social and cultural assets as a community obligation and repackaging viable economic assets and peripheral small services rather than offloading these liabilities without social consideration. This argument highlights the dynamic between the three local factors identified in Figure 1. It shows how enterprise-specific characteristics (e.g. history, traditions) and Vols' relationship with its social community (e.g. high embeddedness and strong social expectations) have been reflected in managers' values and in their restructuring decisions.

In the case of JS, enterprise traditions and pre-1989 management experiences within the context of Jesenice served to effect a lower rate and different pattern of fragmentation. As a SOE, JS had had a reputation for structural experimentation and innovation, as illustrated by frustrated attempts to decentralise in the late $1960 \mathrm{~s}^{3}$. In contrast to Vols, JS's new senior management team consisted of former middle managers rather than former senior managers. Commonly known as aspirants to senior management before 1989, they were anxious, following their appointment, to prove their abilities as modern marketeconomic managers. They immediately appointed a strategic management team under the leadership of the very individual who had been the inspiration for decentralisation efforts twenty years before. The process of voluntary fragmentation started as early as July 1991 and continued apace through to January 1995, when the completely privatised company adopted the holding company form. The enterprise's progressive management culture and the managers' post-communist ambitions spurred JS's managers to adopt radical restructuring policies, while its lower degree of socio-economic embeddedness (there being three other significant providers of social facilities and employment in Jesenice) left their restructuring decisions less constrained by extra-

3 In the climate of the economic reforms of the Dubček era, JS designed decentralised, divisionalised structures. However, the spread of economic normalisation in the early 1970s, in the wake of the 1968 Warsaw Pact invasion and the institution of the Husák regime, brought such experimentation to an abrupt end (see Clark/Soulsby 1999b). 
organisational social commitments. Any residual disagreement over fragmentation among top managers was resolved by a more expedient appeal to the material and non-material benefits that could be acquired by participating in the multitude of boards of directors that sprung up to direct the new holding company and its subsidiaries.

This attention to local factors in the explanation of the fragmentation process highlights the contrast between the conservatism of "limited small fragmentation" of Vols and the radicalism of "extensive large fragmentation" of JS. It points to how the particular patterns of fragmentation in all six enterprises were significantly influenced by a combined effects of enterprise-specific and community factors, mediated through the values and motives of the key decision makers.

\section{Emergent patterns of economic organisation}

Social fragmentation has been quite extensive in most enterprises and has had a major impact on the local social system. Much of this has been forced through State direction, which has reallocated housing and sports facilities, for example, to new non-economic owners. Where social assets have not been fully separated by management decision, this is usually because managers have not been able to realise an acceptable market value or because external factors (such as a restitution claim) have limited their authority to dispose of property. The significant exception to this pattern is illustrated by Vols, whose socioeconomic embeddedness in its community made many social fragmentation decisions unconscionable.

The quantitative increase in legally independent economic units with origins in the assets of former SOEs is irrefutable, but local qualitative materials raise significant questions about the actual extent of their strategic and operational independence. From the limited evidence of six former SOEs in two communities, it is possible to deduce the outlines of four emergent structural patterns of economic organisation, all of which imply a greater tendency towards continuity than change in relations of vertical dependency. On the one hand, functional (e.g. Jekuf) and multi-divisional structures (e.g. Zakov, Vols, and Zachem) are still normal organisational forms, suggesting little change in the independence of enterprise parts.

On the other hand, managers of the larger enterprises have all expressed the desire to move towards a holding company form, a pattern adopted by JS and Vojenz. Evidence of how this form operates within JS - the earliest and most developed example in 1997 - indicates that the creation of formally and legally independent companies within a holding company format does not in itself constitute a move towards the market-economic ideal of multiple, autonomous and competitive firms. Indeed, deeper examination of management processes 
within the seventeen independently registered daughters attests to strong resonances with the past. The holding apparatus has a re-formed appearance, with rules and regulations defining the operational independence of subsidiaries, and therefore qualifies as a mechanism of greater institutional legitimacy in the post-communist world of business. But, its actual functioning is, in the words of one senior manager, like a "feudal system". Prior social ties between managers and enduring technological links between the daughter companies are sufficient to reproduce strong ties of dependence between the new units and the centre. The new corporate system therefore continues to coordinate more or less the same core activities in ways that are informally and operationally reminiscent of the days of the SOE.

The discussion above reveals a fourth structure, which we might call a satellite form. Zachem, in particular, and Vojenz to a lesser extent, have created a large number of small firms through leasing or selling on-site property. On the surface, these "peripheral" businesses offer evidence of more competitive, entrepreneurial and dynamic industrial structures, especially when one considers the myriad post-1989 small firms able to function using former SOE assets. However, far from demonstrating the social construction of independent market-oriented entrepreneurial businesses, for the most part these firms offer small components, energy, design services, canteen services, cleaning services and security services, and are heavily dependent on the former SOEs of which they had been sections. The prognosis for these firms and the economic structures that they create is only as good as the health of the former SOEs with which they are so closely linked through their production, service and, often, social ties.

\section{Conclusions}

The fragmentation of enterprise assets has been an important feature of the emergence of new economic structures from the structural legacies of state socialism. Instead of adopting the generalising statistical approach of transition economists operating within the neo-classical paradigm, this paper has examined the actual processes of fragmentation of six former SOEs grouped within two industrial towns. The picture that emerges is one of diversity in the patterns and types of structural fragmentation. Enterprise fragmentation can be understood as occurring within the wider process of economic and institutional transformation, which set constraints on and opportunities for restructuring different enterprises.

With respect to enterprise restructuring, the transition process in the Czech Republic can be seen as passing though a sequence of four overlapping phases, each associated with different types of fragmentation. In the early phase of continuing state regulation, fragmentation was forced upon the enterprises, often in spite of internal opposition. The fragments created were usually large, 
subsidiary plants that had been major suppliers or recipients of materials or semi-products. In most cases, these new production units were located in other districts. The first wave of voluntary fragmentation arose as a response to economic and institutional shocks. These fragments were far smaller and tended to involve peripheral economic services and social facilities - effectively, bundles of liabilities or assets of marginal value, the separation of which served to make the main production assets look stronger and more viable. This trend continued during the next phase in order to make the core enterprise look more attractive and modern for privatisation. The most significant wave of voluntary fragmentation arose after privatisation had been settled. This mostly took the form of large corporate separations of core production assets and reflected the pronounced move towards the holding company structure.

Although the break-up of the former SOEs has been contextualised by the general exigencies of the macroeconomic transition, its variations can only be understood with reference to a range of local factors, all of which are ultimately filtered through the decisions of key stakeholders. The study of fragmentation at the local level emphasises the important role of enterprise traditions and legacies in shaping the possibilities of and limits to the process. The pattern and type of fragmentation have been related to the nature of the core business before 1990 , to the traditions and values of enterprise management and to the contemporary goals and motives of powerful managers. In turn, these enterprise and management processes are interwoven with the socially accepted role and functions of the enterprise in the local community, indicated, for example, by the degree of socio-economic embeddedness.

The argument presented in this paper suggests that the extent of fragmentation presented through national economic or industrial-sector statistics may not offer a reliable measure of the structural changes in, or health of, the emerging economic system. The findings from local socio-economic research indicate that enterprise fragmentation has not really created the desired expansion of independent, competitive entrepreneurial firms. Indeed, the modes of and motives for enterprise fragmentation observable within local economies may serve to reproduce familiar patterns of vertical dependency in different organisational combinations. More worryingly, by tying the fate of many newly created businesses to the success of their former parents, the emergent economic organisation may institutionalise an industrial fragility to add to the well publicised financial frailties of the privatised Czech system.

\section{Acknowledgements}

The research reported in this paper was only possible because of the contributions of various individuals. Anna Soulsby has worked as a research colleague since the start of the projects from which materials have been collected. I am also grateful to Miloš Keřkovský, Sylva Pešková, Subodh Kumar, Janusz Milerski (Faculty of Business and Management, Technical 
University of Brno) and Pavel Krhánek for their invaluable help as colleagues, organisers, translators and interpreters of culture.

\section{References}

Carlin, W./Landesmann, M. (1997): From Theory into Practice? Restructuring and Dynamism in Transition Economies, Oxford Review of Economic Policy, Vol. 13, pp 77-105.

Charap, J./Zemplinerová, A. (1993): Restructuring in the Czech Economy, EBRD Working Paper No. 2, London.

Clark, E./Soulsby, A. (1996): The Re-formation of the Managerial Elite in the Czech Republic, Europe-Asia Studies, Vol. 48, pp 285-303.

Clark, E./Soulsby, A. (1998): Organization-Community Embeddedness: the Social Impact of Enterprise Restructuring in the Post-communist Czech Republic, Human Relations, Vol. 51, pp 25-50.

Clark, E./Soulsby, A. (1999a): Organizational Change in Post-communist Europe: Management and Transformation in the Czech Republic, London: Routledge.

Clark, E./Soulsby, A. (1999b): The Adoption of the Multidivisional Form in Large Czech Enterprises: the Role of Economic, Institutional and Strategic Choice Factors. Journal of Management Studies, Vol 36, pp 535-559.

Commander, S./Schankerman, M. (1997): Enterprise Restructuring and Social Benefits. Economics of Transition, Vol 5, pp 1-24.

Dlouhý, V./Mládek, J. (1994): Privatization and Corporate Control in the Czech Republic. Economic Policy, Vol 19, pp 156-170.

Etzioni, A. (1988): The Moral Dimension: toward a New Economics, New York: Free Press.

Frydman, R./Rapaczynski, A. (1994): Privatization in Eastern Europe: is the State Withering Away? London: Central European University Press.

Hirschhausen, C. (1995): From Privatization to Capitalization: Industrial Restructuring in Post-socialist Central and Eastern Europe, in: E. Dittrich et al. (eds.), Industrial Transformation in Europe, London: Sage, pp 54-78.

Jeffries, I. (1993): Socialist Economies and their Transition to the Market, London: Routledge.

Kornai, J. (1980): Economics of Shortage, Amsterdam: North Holland Publishing.

Kotrba, J. (1995): Privatization Process in the Czech Republic: Players and Winners, in: J. Svejnar (ed.). The Czech Republic and the Economic Transition in Eastern Europe, San Diego: Academic Press, pp 159-198.

Lízal, L. et al. (1995): Manager Interests, Break-ups and Performance of State Enterprises in Transition, in: J. Svejnar (ed.). The Czech Republic and the Economic Transition in Eastern Europe, San Diego: Academic Press, pp 211-232.

McDermott, G. (1997): Renegotiating the Ties that Bind: the Limits of Privatization in the Czech Republic, in: G. Grabher/D. Stark (eds.). Restructuring Networks in PostSocialism: Legacies, Linkages and Localities, Oxford: Oxford University Press, pp 70106. 
Mejstř́k, M. (1993): Privatization in Czechoslovakia, in: V. Ramanadham (ed.). Privatization: a Global Perspective, London: Routledge, pp 124-140.

Mládek, J. (1993): The Different Paths to Privatization: Czechoslovakia, 1990-? in: J. Earle et al. (eds.): Privatization in the Transition to a Market Economy: Studies in Preconditions and Policies in Eastern Europe, London: Pinter, pp 121-146.

Myant, M. (1993): Transforming Socialist Economies: the Case of Poland and Czechoslovakia, Aldershot: Edward Elgar.

Myant, M. (1999): The Transformation of Czech Enterprises, in: M. Myant (ed.) Industrial Competitiveness in East-central Europe, Aldershot: Edward Elgar, pp 145-169.

Myant, M. et al. (1996): Successful Transformations? The Creation of Market Economies in Eastern Germany and the Czech Republic, Cheltenham: Edward Elgar.

Richet, X. (1993): Transition towards the Market in Eastern Europe: Privatisation, Industrial Restructuring and Entrepreneurship, Communist Economies and Economic Transformation, Vol 5, pp 229-243.

Rychetník, L. (1981): The Industrial Enterprise in Czechoslovakia, in: I. Jeffries (ed.) The Industrial Enterprise in Eastern Europe, Eastbourne, Praeger, pp 114-128.

Soulsby, A./Clark, E. (1995): Privatisation and the Restructuring of Enterprise Social and Welfare Assets in the Czech Republic, Industrial Relations Journal, Vol 26: pp 97109.

Stark, D. (1997): Recombinant Property in East European Capitalism, in: G. Grabher/D. Stark (eds.) Restructuring Networks in Post-socialism: Legacies, Linkages and Localities, Oxford: Oxford University Press, pp 70-106. 